\title{
SOME OBSERVATIONS ON THE OBSERVATIONS THE DECLINE OF THE FRENCH JESUIT SCIENTIFIC MISSION IN CHINA
}

\author{
Florence C. Hsia
}

\begin{abstract}
RÉSumÉ : Dans la Chine de la fin du Xvir siècle, les missionnaires jésuites français ont importé de Paris à Pékin une méthode de recherche scientifique typiquement française et aussi typiquement académique. Ce début prometteur a subi un infléchissement négatif dans le développement ultérieur des ambitions de la mission dans le champ des activités scientifiques de l'Ancien Régime. On analyse ici les différences substantielles qui caractérisent la mission scientifique française jésuite à la fin du $x_{\text {VII }}{ }^{\mathrm{e}}$ siècle et au siècle suivant. À travers une étude des éditions parisiennes de la production scientifique française jésuite en provenance de Chine, les Observations $(1688,1692,1729)$, est expliqué le déclin de la mission scientifique française jésuite par la dissolution de ses liens avec l'Académie des sciences et par ses difficultés à construire et à maintenir une vision collective et une identité de corps dans l'analyse des phénomènes naturels.
\end{abstract}

Mots-Clés : missions jésuites, Chine, Académie des sciences, science, astronomie.

ABSTRACT: In the late seventeenth century, French Jesuit missionaries in China transplanted a distinctively French and distinctively academic brand of scientific work from Paris to Beijing. This auspicious inauguration has obscured the later trajectory of the mission's scientific ambitions within Old Regime arenas of scientific activity. In this paper, I argue that significant differences distinguish the French Jesuit scientific mission in its late seventeenth-century and eighteenth-century incarnations. By examining the various Parisian editions of French Jesuit scientific work carried out on the China mission, the Observations (1688, 1692, 1729), I trace the declining fortunes of the French Jesuit scientific mission to the dissolution of its alliance with the Academie des sciences and to its difficulties in sustaining a corporate identity and collective vision as investigators of natural phenomena.

KEYWoRDs : Jésuit missions, China, Académie des sciences, science, astronomy. 
ZUSAMMENFASSUNG : Im ausgehenden 17. Jahrhundert brachten französische Jesuiten als Missionare eine typisch französische und akademische Methode der naturwissenschaftlichen Forschung nach China. Die vielversprechenden Anfänge wurden vom Niedergang der jesuitischen China-Mission im ausgehenden Ancien Régime überschattet. In dem Artikel werden die Unterschiede zwischen der wissenschaftlichen Aktivität der China-Mission im 17. Jahrhundert und der Entwicklung im 18. Jahrhundert herausgearbeitet. Auf der Grundlage einer Analyse der verschiedenen in Paris erschienenen Ausgaben der Observations (1688, 1692, 1729), in denen die wissenschaftlichen Ergebnisse der Jesuitenmission in China veröffentlicht wurden, wird gezeigt, daß der Niedergang der französischen wissenschaftlichen ChinaMission im wesentlichen zwei Gründe hatte : die Auflösung ihrer Verbindung zur Académie des sciences, und die Unfähigkeit, bei der Untersuchung der Naturphänomene ihre spezifische Identität und Vision zu erhalten.

STICHWÖRTER : Jesuiten, Mission, China, Wissenschaft, Astronomie, Académie des sciences.

RESUMEN : A finales del siglo XVI, importaron los misioneros jesuitas franceses desde Paris hasta Beijing un método de investigación científica tipicamente francesa y también tipicamente académica. Estos primeros pasos muy prometedores se desviaron después con el desarrollo de las ambiciones de la misión francesa en el contexto de la actividad cientifica de su tiempo. Estudiamos aqui los cambios substanciales en la misión científica de los jesuitas franceses entre los siglos XVII y XVIII. El examen de las ediciones parisienses de la producción científica de provenencia china de los jesuitas franceses, o sea las Observations $(1688,1692,1729)$ permite entender la decadencia de esa misión como una consecuencia de la disolución de sus vínculos con l'Académie des sciences y de sus dificultades para construir $y$ conservar una visión colegial y una identidad institucional o corporativa en el análisis de los fenómenos naturales.

Palabras Claves : misiones jesuitas, China, Académie des sciences, ciencia, astronomía.

Née en 1968, Florence C. Hsıa a soutenu une thèse en juin 1999, à l'université de Chicago, sur le travail scientifique et l'étude des sciences chinoises, menés par les jésuites français de Chine aux XVII et XVIII siècles. Elle enseigne l'histoire des sciences à la Wayne State University de Détroit.

Adresse : Department of History, Wayne State University, Detroit, MI 48202, USA.

Courrier électronique : fchsia@ibm.net 
When six Jesuits of the collège Louis-le-Grand set sail from Brest in 1685 for China as mathématiciens $d u$ roi, they inaugurated a new chapter in the history of Jesuit science in the missions. The initial publications in Europe of their scientific work, the Observations physiques \& mathématiques [...] envoyées [...] à l'Académie royale des sciences à Paris par les pères jésuites (Paris, 1688, 1692), set the technical foundations on which French Jesuits in Asia were to maintain a substantive scientific correspondence with the Paris Académie des sciences. Jesuit texts such as Guy Tachard's Voyage de Siam (1686), Louis Lecomte Nouveaux mémoires sur l'état présent de la Chine (1696), and Joachim Bouvet's Portrait historique de l'empereur de la Chine (1697) elaborated a complex formula of Ancien Régime royal ideology rationalizing the work of a Jesuit scientific academy as part of the China mission. At the close of the seventeenth century, the French Jesuit «Académie de la Chine » had transplanted a distinctively French and distinctively academic brand of scientific work from Paris to Peking ${ }^{1}$.

Much recent work has focused on French Jesuit missionary science within its adopted environs of high $\mathrm{Ch}$ 'ing court culture; with good reason, since for the Jesuits, such activities were certainly meant in part to promote their engagement with the Chinese whom they hoped to convert ${ }^{2}$. Yet though they lived for the better part of their lives far from the Jesuit collège and the booksellers on the rue Saint-Jacques, the Maison professe on the rue Saint-Antoine from which Jesuit scriptores edited the Lettres édifiantes et curieuses, the Observatoire royal and the Bibliothèque du roi where members of the Académie des sciences carried out their experiments and observations, French Jesuits in China also continued to read, write, and

1. The leader of the 1685 mission, Jean de Fontenay, referred to his group as an « Académie de la Chine » in an early letter to the Académie royale des sciences (8 Nov. 1687), in Henri BERnARD, « Le voyage du père de Fontenay », Bulletin de l'université l'Aurore, sér. III, t. III, 2, 1942, p. 280.

2. See, for instance, tine growing scholarship on Jean-François Foucquet and his Chinese context : Catherine JAMI, « Jean-François Foucquet et la modernisation de la science en Chine. La Nouvelle méthode d'algèbre », mémoire de maîtrise, université Paris-VII, 1986; ID., «Learning mathematical sciences during the early and mid-Ch'ing ", in Education and society in late imperial China, ed. Benjamin A. ELMAN and Alexander Woodside, Berkeley, University of California Press, 1994, p. 223-256; Jean-Claude MARTzLoFF, « La science astronomique européenne au service de la diffusion du catholicisme en Chine. L'cuvre astronomique de Jean-François Foucquet (1665-1741) », Mélanges de l'École française de Rome. Italie et Méditerranée, t. CI, 1989, p. 973-989; John W. WITEK, Controversial ideas in China and Europe. A biography of Jean-François Foucquet S.J. (1665-1741), Rome, Institutum Historicum Societatis Iesu, 1982, chap. Iv. 
publish as Jesuits "parmi les hommes" of early modern savant France ${ }^{3}$. There is still much to be said about the fortune of French Jesuit scientific ambitions - for ambitions there were - within this cultural ambit. Did the Jesuit « Académie de la Chine » find a European audience for its scientific work? Was it able to maintain a working relationship with the Académie des sciences? Did French Jesuit concern with the natural world, in the context of the China mission, retain coherency and plausibility in the century of the Enlightenment?

I sketch a preliminary answer to such questions by juxtaposing the early Observations $(1688,1692)$ which established a credible textual model for French Jesuit scientific work in China, with the later Observations mathématiques, astronomiques [...] par les pères de la Compagnie de Jésus (1729). I use the two sets of Observations to reveal the declining fortunes of the French Jesuit «Académie de la Chine », the dissolution of the alliance between the Compagnie de Jésus and the Académie des sciences, and the difficulties surrounding eighteenth-century attempts to revive the French Jesuit scientific mission in China.

\section{EDIFYING BUT NOT CURIOUS LETTERS}

The initial cohort of Jesuit mathématiciens $d u$ roi quickly produced an impressive collection of natural historical and astronomical work. Professor of mathematics at the Parisian collège Louis-le-Grand, Thomas Gouye prepared the Observations physiques et mathématiques (1688) from materials he received from his confrères in Siam, publishing the volume with the approval of the Académie des sciences ${ }^{4}$. The Imprimerie royale - responsible for many of the academicians' own publications - printed a second collection of material edited by Gouye in $1692^{5}$. After returning to France,

3. The phrase is borrowed from the title of a recent collection of studies, « Les Jésuites parmi les hommes aux $\mathrm{XVI}^{c}$ et $\mathrm{XVII}^{c}$ siècles $"$, Clermont-Ferrand, Association des publications de la faculté des Lettres et Sciences humaines de l'université Blaise-Pascal, 1987.

4. "Approbation de MM. de l'Académie royale des sciences, » in Thomas Goüye, Observations physiques et mathématiques pour servir à l'histoire naturelle et à la perfection de l'astronomie \& de la géographie, envoyées de Siam à l'Académie royale des sciences à Paris, par les peres jesuites françois qui vont à la Chine en qualité de mathématiciens du Roy. Avec les reflexions de messieurs de l'Academie, \& quelques notes du P. Goüye, de la Compagnie de Jesus, Paris, chez la Veuve d'Edme Martin, Jean Boudot, et Estienne Martin, 1688, p. 278.

5. T. GouYE, Observations physiques \& mathématiques envoyées des Indes \& de la Chine à l'Académie royale des sciences, à Paris, par les pères jésuites, avec les notes \& les réflexions du P. Goüye de la Compagnie de Jésus, Paris, de l'Imprimerie royale, 1692. For academicians' works printed at the Imprimerie royale, see Auguste Bernard, Histoire de l'Imprimerie royale du Louvre, Paris, l'Imprimerie impériale, 1867, p. 140-154. 
Lecomte addressed a letter in his Nouveaux mémoires (1696) to the abbé Jean-Paul Bignon, then president of the Académie des sciences. There Lecomte sketched an "idée générale » of the astronomical and natural historical observations he and his fellow Jesuits had made in Asia, promising a full account of their scientific activities in yet another forthcoming volume $^{6}$. Arriving triumphantly in Canton with new Jesuit recruits for the mission in town, Jean de Fontenay told Leibniz confidently in 1699,

"Nous travaillerons tellement au salut des âmes, que nous n'oublierons pas les sciences, quand l'occasion de faire quelques remarques se presentera. Nous commençons à estre assez de monde pour y fournir, et c'est l'intention du Roy, qui nous a donné des instruments et tout ce que nous pouvions desirer à cet effet ${ }^{7}$."

New recruits for the French mission departed in great numbers in the late 1690s. The Jesuit Charles Le Gobien wrote Leibniz in 1698 that the Jesuit procurator at Paris for the missions, Antoine Verjus, had sent eighteen missionaries to China by various routes ${ }^{8}$. Several factors contributed to a constriction in support for the China mission in the ensuing years : the Jesuits' declining political fortunes in France, a series of decisions at the Sorbonne and Rome in the early eighteenth century against Jesuit views on missionary strategies in China, the adversarial papal legation to the emperor of China in 1705-1710, and an increasingly hostile climate within China itself towards European missionaries ${ }^{9}$. Yet despite a precipitous

6. Louis-Daniel Lecome [Le Comte], Nouveaux mémoires sur l'état présent de la Chine, 2nd ed., Paris, Jean Anisson, 1697; Un jésuite à Pékin. Nouveaux mémoires sur l'état présent de la Chine, 1687-1692, ed. Frédérique Touboul-Bouyeure, Paris, Phébus, 1990, p. 506. See also Verjus-Leibniz (30 March 1695), in Leibniz korrespondiert mit China, ed. Rita WiDMAIER, Frankfurt-am-Main, Vittorio Klostermann, 1990, p. 24 (hereafter cited as LK); BrosseauLeibniz, 8 Oct. 1696, in Gottfried Wilhelm Leibinz, Sämtliche Schriften und Briefe, Darmstadt, O. Reichl, 1923-, series I, vol. XIII, p. 288 ; Journal des savants, 21 Jan. 1697, p. 45 (hereafter cited as $J S$ ).

7. Fontenay-Leibniz, 15 Sept. 1701 , in $L K$, p. 146.

8. Le Gobien-Leibniz, 15 May 1698 , in $L K$, p. 80 . By 1703, some thirty French Jesuits had joined the mission in China. See François Froger, Relation du premier voyage des François a la Chine fait en 1698, 1699 et 1700 sur le vaisseau "L'Amphitrite ", ed. E. A. VorETzSCH, Leipzig, Verlag der Asia major, 1926; the letters penned by French Jesuits from China in 1699 and 1701, in LK and in Lettres édifiantes et curieuses, éd. M. L. Aimé-Martin, Paris, Panthéon, 1843 , t. III, p. 9 (hereafter cited as $L E C$ ). Also consult Joseph DeHERGNE, Répertoire des jésuites de Chine de 1552 à 1800, Rome/Paris, Institutum Historicum Societatis lesu/Letouzey \& Ané, 1973.

9. French Jesuit superiors at Paris told Fontenay before his voyage back to China in 1701 that they did not intend to send more personnel for « some years »; see Gerbillon-Le Gobien, 8 Oct. 1701, repr. in Yves DE ThomAZ DE Bossierre, Jean-François Gerbillon, S.J. (16541707), Leuven, Ferdinand Verbiest Foundation, 1994, p. 131. For a frank evaluation of these issues and the state of the China mission in 1709 , written « between friends » - from one Jesuit to another - see Le Coulteulx-Souciet, Oct. 1709, Revue de l'Extrême-Orient, t. III, 1887 , p. 32-39 (hereafter cited as $R E O$ ). On French Jesuit political, theological, and ecclesiastical difficulties in the early eighteenth century, see Catherine M. Northeast, The Parisian 
decline in new recruits for the China mission, the large cohorts which reached China around the turn of the century provided enough potential manpower to fulfill the vision of a French Jesuit scientific mission elaborated in the Jesuits' Paris publications of the 1680s and 1690s.

Fontenay's permanent return to France in 1703 , however, marked a virtual suspension of French Jesuit scientific work on the mission, as Fontenay himself and his successors in China later acknowledged ${ }^{10}$. The sizable number of Jesuit missionary letters from China included in the Lettres édifiantes et curieuses, edited from 1702 on by Jesuits at Paris, made but occasional passing references in the early decades of the century to the usefulness of science for advancing the Christian mission in China ${ }^{11}$. Only Fontenay, in two letters he penned en route to France in 1703 and 1704, explicitly discussed the program of scientific work that he and his confrères of 1685 had founded in alliance with the Académie, and that Jesuit texts of the 1680s and 1690s had trumpeted so prominently. Yet Fontenay referred but incidentally to French Jesuit scientific work in these letters, interspersing brief descriptions of such activity throughout a running narrative of his experiences in China ${ }^{12}$. This sort of anecdotal reportage characterizes most of the scattered contributions to the Lettres édifiantes which were "curieuses" in discussing Jesuit deployment of astronomical, cartographical, or medicinal knowledge in China. From the use of cinchona to lift the K'ang-hsi emperor's fever to a Jesuit-led cartographical project undertaken at the emperor's behest, such instances of French Jesuit scientific work were typically introduced in the pages of this journal of the Jesuit overseas missions as testimony to the edifying enterprise in China ${ }^{13}$. More rare were descriptions of an area's flora, fauna, and climate within sum-

Jesuit and the Enlightenment, 1700-1762, Oxford, Voltaire Foundation, 1991, chap. I, and Paul A. Rule, K'ung-tzu or Confucius? The Jesuit interpretation of confucianism, Sydney, Allen \& Unwin, 1986, p. 134-149.

10. See Fontenay-Leibniz, 10 Sept. 1705, in $L K$, p. 227, 230; Gaubil-Souciet, 28 June 1726, in Correspondance de Pékin, 1722-1759, ed. Renée Simon, Genève, Droz, 1970, p. 119; Gaubil-Souciet?, 1733?, in R. Simon, ibid., p. 357. For the date of Fontenay's departure from China, see Fontenay-Leibniz, 13 June 1704 , in $L K$, p. 200.

11. Until the publication in 1726 of Dominique Parennin's 1723 letters to the Académie des sciences. I discuss this case below.

12. See $L E C$, t. III : Fontenay-La Chaise, 15 Feb. 1703, p. 84-86, 88, 95, 96, 101, 105, and Fontenay-La Chaise, 15 Jan. 1704, p. 118-119.

13. See in $L E C, \mathrm{t}$. III, general allusions to science in service to religion : Emeric Langlois de Chavagnac-Charles Le Gobien, 30 Dec. 1701, p. 52; François-Xavier Dentrecolles-JeanCharles-Étienne Froissard de Broissia, 10 May 1715, p. 240. For European medicinal remedies, see in ibid. : Jean de Fontenay-François de La Chaise, 15 Feb. 1703, p. 106-108; Jean Gerbillon, 1705, p. 159; Dentrecolles-le père procureur général des missions des Indes et de la Chine, 17 July 1707, p. 163 and Dominique Parennin's éloge for Bernard Rhodes, 27 March 1715 , p. 236-238. On the mapping project, see ibid. : Gerbillon, 1705, p. 157-158; Dentrecolles-Broissia, 10 May 1715, p. 253; Jean Domenge, 1 July 1716, p. 270. Cf. Joseph Marie Anne de Moyriac de Mailla's unique complaint that the mapping project had interfered with his missionary tasks, in ibid. : Mailla-Colonia, Aug. 1715, p. 253-254. 
mary natural and moral histories of particular regions ${ }^{14}$, or sustained discussions of Chinese herbs and manufactures ${ }^{15}$.

The coherent program of investigating nature articulated in the initial publications stemming from the French Jesuit mission in China had, in the page of the Lettres édifiantes et curieuses, dissolved into an assortment of idiosyncratic contributions to a journal primarily devoted to documenting Jesuit missionary activity in China. It was not until 1729 that a new volume of Observations mathématiques, astronomiques, géographiques, chronologiques et physiques was published at Paris ${ }^{16}$. The first monographic presentation of astronomical, natural historical, physical, and geographical work carried out by Jesuits in China to appear since the Observations of 1688 and 1692 , the tome included but nine astronomical observations made by French Jesuits between 1708 and 1720 : a slim dossier, dwarfed in both quantity and complexity by the astronomical work made by the president of the Astronomical Bureau, the German Jesuit Ignatius Kögler, following his arrival in China in 1717, and by Antoine Gaubil after his arrival in $1722^{17}$. Similarly, the seven observations of magnetic declination made by French Jesuits between 1708 and 1711 and included in the Observations of 1729 were followed by Gaubil's log of eighty separate recordings made en route from France to China in 1721 and $1722^{18}$. Close inspection of French Jesuit publications, then, reveals a prolonged lapse in organized scientific work on the China mission. How did the Jesuits explain this lapse?

\section{EXTERNAL OBSTACLES}

The initial texts documenting French Jesuit scientific work in China had adverted to certain difficulties in carrying out scientific tasks, establishing a

14. See $L E C, t$. III : Claude Jacquemin on the island of Tsong-ming, 1 Sept. 1712, p. 196206, Mailla on Formosa, Mailla-Colonia, Aug. 1715, p. 254-267, and Jean Jacques' account of his journey to China, Jacques-abbé Raphaelis, 1 Nov. 1722, p. 316-326.

15. See $L E C$, t. III; Pierre Jartoux's letter of 12 April 1711, p. 182-187, in which Jartoux provides a natural history of ginseng, and Dentrecolles' accounts of porcelain manufacture, 1. Sept. 1712, 25 Jan. 1722, p. 207-224, 309-316.

16. Étienne SOUCIET, Observations mathématiques, astronomiques, géographiques, chronologiques, et physiques, tirées des anciens livres chinois ou faites nouvellement aux Indes et à la Chine par les pères de la Compagnie de Jésus, t. I, Paris, Rollin, 1729. Tomes II and III appeared in a single volume in 1732 .

17. And this despite Antoine Gaubil's best efforts in canvassing the archives kept at the French mission house in Peking for his predecessors' scientific work. See É. SoucdeT, op. cit. supra n. 16, t. I, p. 12-16, 31-106, and Gaubil-Souciet, 28 June 1726, in R. Simos, op. cit. supra n. 10 , p. 119 . The astronomical observations made by Jean-Baptiste Régis, Pierre Jartoux and other French Jesuits prior to Gaubil's arrival appear on p. 12, 32, and 35-38, mostly observations of lunar eclipses.

18. See É. Soucat, op. cit. supra n. 16, t. 1, p. 209 (Régis and Jartoux); p. 210-221 (Gaubil). 
set of conventional excuses for the missionary-scientist abroad. Gouye assured his readers in the preface to his 1692 volume that

« [...] les mêmes Jésuites François ont continué à observer sur les Instructions de l'Académie, autant que leur ont permis les révolutions arrivés à Siam, les longs \& pénibles Voyages qu'il leur a fallu faire, les maladies, la prison de plusieurs entr'eux, l'étude des Langues Indiennes, Tartare \& Chinoise, \& le ministère de l'Évangile, qui fait leur occupation principale ${ }^{19}$.

A few years later Lecomte lamented the lost Jesuit observatory in Siam, the construction of which was well underway when political disaster in 1688 forced its abandonment. Like Gouye, he argued that studying the languages needed for missionizing and preaching the gospel had for the moment prevented the Jesuits from fulfilling their "vast design " for extending the Académie's scientific program throughout their missions ${ }^{20}$.

Imperial attitudes towards the presence of Jesuits and other European missionaries in the provinces had worsened dramatically in the eighteenth century, reducing the number of missionaries in the interior, restricting their mobility, and adversely impacting the scope of their activities ${ }^{21}$. Bouvet confided to Leibniz that the court context within which he and his confrères had scored their most prominent successes in promulgating the Académie's mathematical, anatomical, and natural philosophical texts recounted at length in his glowing 1697 portrait of the K'ang-hsi emperor - was not so receptive to such efforts after his return to China in $1699^{22}$. Fontenay remarked in 1704 that the emperor « no longer seemed to have the same eagerness for mathematics and for the other sciences of Europe in which he had made himself so skilled ${ }^{23} »$. Drawing on Dominique Parennin's explanation for the practical impossibility of botanizing in China, Fontenelle wrote in the Académie's published Histoire for 1726,

"Quel vaste champ pour herboriser! Mais les Missionnaires n'en ont pas la commodité qu'on s'imagineroit ici. Il ne faut pas s'arrêter à des regrets sur un sujet si particulier, toutes les sciences Européennes vont être étouffées à la

19. T. GouYe, op. cit. supra n. 5, repr. in Mémoires de l'Académie royale des sciences, depuis 1666 jusqu'à 1699, Paris, par la Compagnie des libraires, 1729-1733, t. VII, part. 2, p. 743 (hereafter cited as MARS 1666-1699).

20. L. D. LeCOMTE, op. cit. supra n. 6 , p. 507.

21. Consult the handy chronology in J. Dehergne, op. cit. supra n. 8, p. 332-341.

22. Bouvet-Leibniz, 4 Nov. 1701, in $L K$, p. 159. Joachim Bouvet, Portrait historique de l'empereur de la Chine, présenté au Roy, Paris, Étienne Michallet, 1697; I have used the La Haye edition of 1699, Histoire de l'empereur de la Chine, fac simile repr., Tientsin, 1940.

23. He noted, nevertheless, that the emperor much favored two of the more recently arrived French Jesuits for their mathematical and mechanical knowledge. Fontenay-La Chaise, 15 Jan. 1704, in $L E C$, t. III, p. 118-119. Cf. Jartoux-Leibniz, 10 Oct. 1703, in $L K$, p. 198. 
Chine dans leur naissance, puisqu'on n'y veut plus recevoir les habiles gens qui y portoient la double lumière de ces sciences \& de la religion ${ }^{24}$. »

Étienne Souciet claimed instead that the very success of French Jesuit academic science in China had delayed his confrères in fulfilling their obligations to the Académie. He explained in his preface to the 1729 Observations that his fellow Jesuits in China had been " overwhelmed " by other tasks, such as the K'ang-hsi emperor's desire for instruction in mathematics, philosophy, anatomy, and «other sciences of Europe", and the need to translate relevant texts into Manchu and Chinese for the emperor's and his sons' benefit. Souciet suggested that these « occupations » had prevented them from pursuing their scientific work " with the same assiduity " in the intervening years; European publication of their observational work in connection with the emperor's map project had been delayed only because it would appear together with the maps themselves ${ }^{25}$.

The public rhetoric of excuses for the lapse in French Jesuit scientific work in China, however inconsistent, did not suggest a lack of will or expertise on the Jesuits' part, focusing rather on obstacles external to their good intentions and presumed abilities. But when Gaubil finally saw a copy of the Observations (1729), he was mortified by Souciet's «tours fins pour faire valoir en général nos P.P. et en particulier pour donner des raisons plausibles qui ont jusqu'ici, c'est-à-dire depuis le P. de Fontenay, empêché nos P.P. de faire ou d'envoyer les observations astronomiques ${ }^{26} »$. Gaubil knew first-hand the problems which had plagued his own efforts to revive French Jesuit scientific activity in China after his own arrival in 1722. It is to these underlying and unarticulated problems that we now turn.

\section{FONTENAY'S FAILURE}

The language of collaborative scientific work and of a corporate scientific persona, borrowed from the Académie and articulated in the French Jesuits' early publications, masked the divergence of skills and interests

24. Histoire de l'Académie royale des sciences, avec les mémoires de mathématiques \& de physique, pour la même année, tirées des registres de cette Académie, Paris, de l'Imprimerie royale, 1702-1797 (hereafter cited as HARS, when citing from the Histoire, and as MARS, when citing from the Mémoires). Bernard Le Bovier de Fontenelle, in HARS, 1726, p. 20; Parennin-Fontenelle, 15 Oct. 1723, in LEC, t. III, p. 344-345.

25. É. SoucieT, op. cit. supra n. 16, t. I, p. VIIIIX.

26. Gaubil-Souciet, 16 Aug. 1731, in R. Simon, op. cit. supra n. 10, p. 274. 
among those who sailed for the East. There is little evidence that the initial cohort of 1685 consisted of individuals selected for their experience in the tasks and responsibilities invested in them by the alliance with the Académie. The work of Jesuit professors of mathematics and hydrography in French collèges during the latter half of the seventeenth century made plausible an expectation that the Compagnie de Jésus might readily provide a pool of personnel appropriate to the Académie's needs. But of the six chosen for the 1685 voyage to China, only Fontenay as the senior member of the expedition was representative of such a pool, having taught mathematics and hydrography at Nantes and Paris for a decade, edited his predecessor Ignatius Pardies' star charts, published his own astronomical observations, and established himself as a working member of the community of Parisian astronomers.

Jesuit publications tended to efface Fontenay's role as a linchpin for the new French Jesuit scientific program in China. But his friendship with Parisian academicians was crucial in procuring, for instance, Jean-Dominique Cassini's tables for Jupiter's moons, corrected in manuscript and not republished until 1693, and Cassini in his commentary on the Jesuits' observations tended to address Fontenay personally as a colleague and interlocutor $^{27}$. In practice, moreover, Fontenay carried the burden of the astronomical observations - the most prominent as well as the most technically complex aspect of the work which the French Jesuits promised to undertake for the Académie. An eighteenth-century inventory of the Académie's manuscripts shows that the number of observations made by Fontenay between 1688 and 1691 far exceeded those made in the same period by Claude de Visdelou and Louis Lecomte at their mission at Jiangzhou in Shansi province, and by Joachim Bouvet and Jean-François Gerbillon at Peking $^{28}$. Indeed, Fontenay's observational log for 1689 and 1690 provided the only materials, astronomical or otherwise, produced by the French Jesuit mission in China to appear in the Observations of $1692^{29}$.

27. See J. Bouvet's manuscript journal, Voiage de Siam du père Bouvet (1686), ed. Janette C. GatTy, Leiden, E. J. Brill, 1963, p. 8; Guy TAChARd, Voyage de Siam des peres Jesvites envoyes par le roy, aux Indes \& a la Chine, avec leurs observations astronomiques, \& leurs remarques de physique, de géographie, d'hydrographie, \& d'histoire, Paris, Chez Arnould Seneuze, 1686; I have used the Amsterdam edition by Pierre Mortier of 1687, p. 6-7. For confirmation that the French Jesuits took Cassini's corrected tables, see MARS 1666-1699, t. X, p. 697; T. GouYE, op. cit. supra n. 5, repr. in MARS 1666-1699, t. VII, part. 2, p. 759, 763. For Cassini's commentary, see T. GouYE, op. cit. supra. n. 4, p. 97, 98, 95.

28. See Alexandre-Guy Pingrés Annales célestes du dix-septième siècle, ed. Guy BigourDAN, Paris, Gauthier-Villars, 1901, for Fontenay's observations, p. 445, 452-454, 468-471, 474 (with Lecomte), 476, 481-485, 494; for observations by Bouvet and Gerbillon, p. 471, $474,481-485,486$; for observations by Lecomte and Visdelou, p. 444, 452-454, 457, and see L.-D. LecomTE, op. cit. supra n. 6, p. 510-511.

29. Even though readers were told that some of Fontenay's materials had been partly lost at sea; see Gouye's preface to the Observations (1692), repr. in MARS 1666-1699, t. VII, part. 2, 
In a letter to the Académie des sciences written shortly after arriving in China, Fontenay wrote that he and his confrères intended to divide their scientific work among them. Within the «Académie de la Chine », Fontenay alone was charged with « the history of Chinese astronomy and geography, and the daily observations of the sky corresponding to those made at Paris in the Observatory ». The others were each to take up a specific field : Visdelou, the study of Chinese history and language; Bouvet, that of natural history and Chinese medicine; Lecomte, the history of the liberal and mechanical arts; and Gerbillon, Chinese laws, government, and customs, in addition to « the other parts of physique » not covered by Bouvet. Fontenay explained that such an arrangement would allow the missionaries time to attend to their other duties, presumably relating to the edifying mission. It would be impracticable, moreover, for each individual to take on the entire range of scientific investigation, and the arrangement would allow each individual the time "pour exécuter en effet plus de choses ensemble et pour les exécuter avec plus de soin et d'exactitude, car nous savons qu'on s'affectionne pour l'ordinaire plus à ce qui nous touche plus particulièrement, et que l'on se rend aussi plus consommé dans une science quand on s'y adonne tout à fait ». This was precisely why, Fontenay suggested, the Académie itself was composed of geometers, astronomers, and other specialists, «bien que chacun de vous ait le mérite qu'il faut pour exercer toutes ces fonctions ensemble ${ }^{30}$.

The tension between the individual and the communal experienced by would-be Jesuit academicians in China paralleled Académie struggles with similar issues ${ }^{31}$. Anonymous attribution of scientific labor to the French Jesuits in China as a group, which characterized Tachard's Voyage de Siam (1686) and Gouye's Observations (1688), was abandoned in later Jesuit publications. In the 1692 Observations, Gouye organized the materials according to their respective authors, with different first-person Jesuit voices appearing frequently, and both Lecomte and Bouvet in their more

p. 743. The balance of the volume consisted of observations made by French Jesuits in southeast Asia - former members of the dispersed Siam mission - and the Belgian Jesuit Francois Noel in China.

30. Fontenay-Messieurs de l'Académie royale des sciences, 8 Nov. 1687, in H. Bernard, art. cit. supra n. 1 , p. $279-280$.

31. Cf. articles 20 and 22 of the 1699 règlement, repr. in L'Institut de France. Lois, statuts, et règlements concernant les anciennes académies et l'institut, ed. Léon Aucoc, Paris, Imprimerie nationale, 1889, p. Lxxxrv-xcIr. See Lorraine J. Daston, « Classifications of knowledge in the age of Louis XIV ", in Sun King. The ascendancy of French culture during the reign of Louis XIV, ed. David Lee RuBIN, Washington, D.C./Londres/Toronto, The Folger Shakespeare Library/Associated University Presses, 1992, esp. p. 209-211; Roger HaHN, The Anatomy of a scientific institution. The Paris Academy of sciences, 1666-1803, Berkeley, University of California Press, 1971, p. 24-30; and Alice STroup, A company of scientists. Botany, patronage, and community at the seventeenth-century Parisian Royal Academy of Sciences, Berkeley, University of California Press, 1990, p. 205-209. 
popular works reiterated the fact of a division of labor within the French Jesuit scientific mission, an arrangement perpetuated in later cohorts of missionaries ${ }^{32}$. Yet this division of scientific labor along disciplinary lines was not in itself incompatible with a rhetoric of corporate scientific identity and collaborative endeavor for a common good, albeit in a more loosely conceptualized model of cooperation ${ }^{33}$. The institutional model provided by the Académie allowed for such individual specializations to coexist within a robust corporate identity, and as we have seen, architects of the French Jesuit « Académie » in China such as Fontenay spoke unproblematically of both their confrères' individual research and of their collective effort to perfect the arts and sciences.

The division of labor acknowledged, however, that Fontenay alone had the expertise to carry out the full program of astronomical observations desired by the Académie des sciences. This fact had significant consequences for the French Jesuit scientific mission's much-trumpeted alliance with the Parisian institution. Astronomical work was, after all, the most prominent feature in the academic model of science as the French Jesuits adopted it. We should recall that the «manières d'observer » which Cassini and other academicians claimed as the Académie's, and which the French Jesuits, in turn, took up as a key part of their identification with the Académie, concerned astronomical practice ${ }^{34}$. Philippe de La Hire remarked that it was precisely because the Jesuits intended for the China mission had been instructed «dans ces manières d'observer » practiced by the astronomers at the Observatoire royal, that Louis XIV had decided to incorporate (aggreger) the Jesuits into the Académie ${ }^{35}$. Certainly in the Observations of 1688 , natural history took a back seat to « the perfection of astronomy and geography " as announced in the title ${ }^{36}$. The 1692 Observations contained no natural historical material at all, concentrating almost entirely on astronomy and geography ${ }^{37}$. It was, moreover, with Académie

32. L.-D. LecomTe, op. cit. supra n. 6, p. 506-507; J. Bouvet, op. cit. supra n. 22, p. 160. See F. Froger, op. cit. supra n. 8, p. 100, for a similar division among the Jesuits who accompanied Bouvet on his journey back to China in 1698 .

33. Thanks to David Hull for pushing me to rethink this point.

34. Florence C. HsIA, « Jesuits, Jupiter's satellites, and the Académie royale des sciences », in The Jesuits. Cultures, sciences, and the arts, 1540-1773, ed. John W. O'MALLEY, Gauvin A. Bayley, Steven J. Harris and T. Frank Kennedy, Toronto, University of Toronto Press, 1999, p. 241-257.

35. Philippe de La Hire, in T. Gouye, op. cit. supra n. 4, p. 116; see also Jean-Dominique CAssinI, « De l'origine et du progrès de l'astronomie et de son usage dans la géographie et dans la navigation ", in Recueil d'observations faites en plusieurs voyages par ordre de sa Majesté, pour perfectionner l'astronomie et la geographie, avec divers traitez astronomiques, par messieurs de l'Académie royale des sciences, Paris, de l'Imprimerie royale, 1693, p. 43.

36. In the 1688 Observations, the Jesuits' " anatomical descriptions " of various Siamese animals take up the first 60 pages; the balance of the 278 -pp. text is devoted to astronomical observations and to related geographical determinations.

37. See Jean Gallors' review, « Extrait du livré intitulé Observations physiques \& mathé- 
astronomers that the French Jesuit mission to China, via Fontenay, had its strongest personal ties. Fontenay's presence on the mission, and the perpetuation of his particular line of scientific work - of all the assorted fields covered by the French Jesuits - take on considerable importance from this perspective. The observational program in astronomy endorsed by the Académie was both the capstone of the French Jesuits' alliances with the Académie, and the most important marker of the French Jesuit scientific mission's corporate identity. Without it, the French Jesuits' interests in the investigation of nature fragmented, each individual pursuing particular topics without the benefit of an overarching vision of collaborative scientific work. The division of labor the French Jesuits in China espoused - an eminently practical solution to divergent interests and skills - meant that it was all too easy for such interests to go their separate ways when the pressures of the Rites Controversy and Fontenay's departure brought additional centrifugal forces to bear ${ }^{38}$. Fontenay had no immediate successor in astronomical work on the China mission; nor did any member of his cohort, or of the second generation of new recruits in the late 1690 s and early 1700 s, possess similar contacts with academicians of any stripe. Fontenay's failure, if we can call it that, was in leaving the French Jesuit scientific mission in China without leadership ${ }^{39}$.

THE COMPAGNIE AND THE ACADÉMIE

Nearly forty years after Gouye had brought out his two volumes of French Jesuit scientific work in China, the librarian of the Parisian collège

matiques envoyées des Indes \& de la Chine à l'Académie royale des sciences, à Paris, par les pères Jésuites, avec les notes \& les réflexions du P. Goüye de la Compagnie de Jésus. À Paris, de l'Imprimerie royale ", 31 June 1692, in MARS 1666-1699, t. X, p. 131-137. The few "observations physiques" of the title - of tides, magnetic declination, temperature, and barometric recordings - comprise about $15 \%$ of the volume. Claude DE BĖzE, whose astronomical contributions appeared in the Observations (1692), also wrote the brief \& Descriptions de quelques arbres et de quelques plantes de Malaque », published much later in the Académie's eighteenth-century collected volumes of materials from the early decades of its existence, in MARS 1666-1699, t. IV, p. 327-333.

38. Certainly the Rites Controversy provided a more immediate and no doubt more compelling governing rubric for some of the French Jesuits. For Bouvet's radical proposal for a French Jesuit «petite Académie », see Bouvet-Leibniz, 4 Nov. 1701, in $L K$, p. 158-159; Bouvet-Leibniz, 8 Nov. 1702, in $L K$, p. 176-177; Bouvet's letters published in Eine wissenschaftliche Akademie für China, ed. Claudia von Collani, Stuttgart, Franz Steiner Verlag Wiesbaden, 1989; and P. A. Rule, op. cit. supra n. 9, chap. III.

39. Fontenay's efforts to initiate a program of regular astronomical observations in Peking during the 1690 s with Gerbillon's help met with little success. Gaubil remarked years later that the astronomical observations which Fontenay and Gerbillon had made there with Bouvet were "very few in number and of little consequence ", adding that nonetheless the observations were « very good, and Father Fontenay was a master »; Gaubil-Souciet?, 1733?, in R. Simon, op. cit. supra n. 10, p. 357; cf. Gaubil-Delisle, 25 Oct. 1750, in ibid., p. 614. 
Louis-le-Grand announced the resurrection of the French Jesuit scientific mission in China. In his preface to the Observations (1729), Souciet deliberately placed the book in a textual lineage whose precedents had been set so many decades earlier. Lauding his confrères Antoine Gaubil and Jean Jacques, who departed France for the China mission in 1721, Souciet noted Gaubil's profound mathematical knowledge, Jacques' «talent and inclination for experiences and Observations ", and the assiduity with which both Jesuits undertook their scientific work in Asia after having conferred «several times » with Jacques Cassini and Giacomo Filippo Maraldi, then the Académie's senior astronomers ${ }^{40}$. Souciet recounted the founding of the French Jesuit mission to China as an enterprise endorsed by both King and Académie : how Louis XIV had provided the Jesuits with scientific instruments and made them "mathématiciens du roi "; how the Académie des sciences had «instructed them and communicated their [lights] to them »; how the Académie had approved the Jesuits' observations, and the public Gouye's subsequent editions of the Jesuits' scientific labor ${ }^{41}$. Souciet reminded Louis XV in the dedication that his illustrious predecessor had honored the French Jesuits in 1685 with " the title of his Mathématiciens ", both to " accredit their Apostolic Ministry " and to « animate " them towards the «tiresome exercise of Observations». The Jesuit royal mathematicians had « responded perfectly to the intentions of this glorious Monarch, and the fruit of their labors, which was then published, is the proof of it ". In the same way, the present work was to serve as evidence that their contemporary successors were no less worthy of the title ${ }^{42}$. Souciet quoted a short testimonial from Maraldi, and declared his desire to «begin again, if possible, where this Father [Gouye] had finished » with a new volume of Jesuit « observations », numbering nearly 300 quarto pages ${ }^{43}$.

Souciet rehearsed this history of the mission's founding as a prelude to presenting the Observations as evidence for the renewal of the French Jesuit scientific mission in China, assuring readers of his hope that his confrères' work be « reestablished and continued with more exactitude and perseverance than ever ${ }^{44} »$. But the break in the tradition of French Jesuit scientific work in China could not be patched over by such prefatory flourishes, which belied significant differences between the French Jesuit scientific mission of the late seventeenth century and its eighteenth-century

40. É. SoucieT, op. cit. supra n. 16, t. I, p. IX-XII.

41. Ibid., p. vi-vis.

42. Ibid., sig. aiiir-aiiiir (épître).

43. Ibid., p. XVIII, XII-XIII.

44. Ibid., p. Ix. 
incarnation. To begin with, Gaubil and Jacques went to China without any formal markers of affiliation with the Académie ${ }^{45}$. Completely missing from Souciet's discussion was any mention of Gaubil and Jacques as académiciens, in dramatic contrast to the rhetoric in late seventeenth-century Jesuit publications concerning the French Jesuit mission in China. With the reforms of the Académie des sciences in 1699, the status of many individuals with various sorts of connections to the Academy was regularized under the category of correspondant. The royal règlement promulgated in early February of that year clarified categories of Academy membership, i. e. honoraire, pensionnaire, associé, and élève. As David J. Sturdy has noted, the règlement also mandated that the Académie should « maintain contact with various savants in Paris, the provinces and abroad », and so the academicians agreed to name correspondents - worthy individuals who lived more than twelve leagues from Paris - to be attached to particular Académie members ${ }^{46}$. Of the thirteen Jesuit correspondents named in March 1699, seven were associated with the China mission. They included Fontenay, Bouvet, Visdelou, and Gerbillon, that is, those charter members of the 1685 voyage still in China ${ }^{47}$. Their admittance into the Académie in 1685 - a membership exploited so elaborately in French Jesuit texts of the 1680 s and 1690 s - was retrospectively revised in light of the institution's formalized structure ${ }^{48}$. As the title pages to the eighteenth-century republication of Gouye's volumes in the Académie's collected works made clear, the French Jesuits in China were correspondants - a pragmatic category of association carrying neither voice within the Académie, nor the per-

45. Souciet's emphasis on his confrères' status as mathématiciens du roi mirrored that of Tachard and Gouye with respect to the 1685 missionnaries. Gaubil and Jacques' royal brevets followed precisely the same formulations of the petites lettres patentes carried by the members of the 1685 voyage, which commissioned the Jesuits "en cette qualité " of mathematician to « travel to the Indies and China to there make all the said observations for the perfection of the arts and sciences and the exactitude of geography ». See É. SoucIET, ibid., sig. aiiir-aivr (épître), and p. vi-v11 (préface); "Brevet de mathématicien », 17 March 1721, in R. SIMON, op. cit. supra n. 10, p. 9; and the text of the patent letters published by Tachard in 1686. But being a mathématicien du roi did not itself entail formal affiliation with the Académie.

46. David J. Sturdy, Science and social status. The members of the Académie des sciences, 1666-1750, Rochester, NY, Boydell Press, 1995, p. 287.

47. Joachim Bouvet, Antoine Chomel, Jean de Fontenay, Jean Gerbillon, Jean-Alexis de Gollet, Jean-Baptiste de Saint-Leu, Claude de Visdelou; see Index biographique des membres et correspondants de l'Académie des sciences du 22 décembre 1666 au 15 décembre 1967, Paris, Gauthier-Villars, 1968, sub nom. Of the six Jesuit «mathématiciens du roi » who had set out in 1685, Tachard never set foot in China, becoming involved with the Jesuit effort in Siam, and later in the East Indies missions; Lecomte had returned to France permanently in 1691 .

48. On the Jesuits' admittance to the Académie, see G. TACHARD, op. cit. supra n. 27, p. 6; J. BouveT, op. cit. supra n. 27, p. 15; P. DE LA HiRE, in T. GouYe, op. cit. supra n. 4, p. 116. 
manency of a pension - and Souciet did not repeat earlier claims for Jesuit membership in the Académie ${ }^{49}$.

Still, the Jesuits retained a presence within the Académie proper. Gouye, the editor of his confrères' scientific work in China, was named an honoraire in $1699^{50}$. Even with the reduction of the French Jesuits in China to the status of correspondant, Gouye's position might have given his confrères in China at least some opening for continued association with the Académie. The role of Jesuit "middlemen " at Paris - brokering the Jesuits' work to an interested and sympathetic audience, and cajoling positive responses and support of both a material and less tangible variety was vital to the continued existence of the Jesuit mission in China ${ }^{51}$. Such was the role Verjus and Le Gobien had taken on earlier in the century by « favoring » Leibniz's correspondence with their confrères in China and by providing cover letters which expressed esteem for such a prominent supporter of the Jesuit missions ${ }^{52}$. The trade Jesuit procurators drove in cultivating these informal networks paralleled that of Jesuit editors like Le Gobien, who, charged by his superiors as early as 1698 with « writing the history of [their] missions and with giving to the public all which comes to [them] from China ", sought to make the best of their confrères' writings through publication ${ }^{53}$.

Just such a mediating role had been crucial in the successful welding of French Jesuit scientific activity to an academic framework. As Fontenay's successor as professor of mathematics at the Jesuit collège Louis-le-Grand, Gouye quickly cultivated relationships with Parisian academicians. In 1686, Gouye dedicated his «Thèses de mathématique » to the Académie ${ }^{54}$, and from 1692 to 1694 co-edited several volumes of the Académie's Mémoires de mathématiques et de physique, tirés des registres de l'Académie des sciences with de La Hire ${ }^{55}$. Gouye's editorial work was invaluable

49. See MARS 1666-1699, t. VII, part. 2, sig. aiir r ${ }^{\circ}$ and MARS 1666-1699, t. III, part. 2, p. 251. The practice of naming correspondants was only formalized by the règlement of 1753 . See L. Aucoc, op. cit. supra n. 31, p. XcvIII-c.

50. The règlement specified in article 12 that no member of a religious order could be proposed for a place as academician except as an académicien honoraire. In practice, the only other sort of membership open to a religious besides that of honoraire, at least until 1716, was that of correspondant.

51. A. STroup makes a similar point concerning the mediating role played by Parisian Jesuit « brokers ", including Gouye, between French Jesuit provincial astronomers and the Académie in « Le Comté Venaissin (1696) of Jean Bonfa, S.J. A paradoxical map by an accidental cartographer », Imago Mundi, vol. XLVII, 1995.

52. See e. g. Leibniz-Verjus, 18 Aug. 1705, in $L K$, p. 213 passim.

53. Le Gobien-Leibniz, 15 May 1698 , in $L K$, p. 80 ; see J. Dehergne, op. cit. supra n. 8 , p. 317.

54. See A. Stroup, op. cit. supra n. 31, p. 332, n. 65.

55. Mémoires de mathématiques et de physique, tirés des registres de l'Académie des sciences, 4 vol., Paris, l'Imprimerie royale, 1692-1694. 
for both the 1688 and 1692 Observations. When the secretary of the Académie, the abbé Jean Gallois, reviewed Gouye's second volume, he noted that the Jesuits abroad had sent « some simple Observations without order and without any reflections », but Gouye had «sorted them, drafted them into order, brought them to light, compared them with M. Cassini's Ephemerides of the Satellites of Jupiter, and [...] had drawn from this comparison the consequences which are, so to speak, the soul of this book ${ }^{56}$. Gouye carefully emended the materials sent by his confrères from all over Asia, refined them in light of academicians' interests and research, and solicited academicians' responses to appear alongside the Jesuits' work $^{57}$. This editorial labor resulted in texts which, even in the late $1720 \mathrm{~s}$, were viewed as academic works. Both of Gouye's volumes were reprinted in 1729 as part of the Académie's Mémoires de l'Académie royale des sciences, depuis 1666 jusqu'à 1699, in the volume devoted to "Observations faites en plusieurs voyages ${ }^{58}$ ».

A vital liaison between his Jesuit brothers in the missions and the Académie in Paris, Gouye should have been well poised as an honoraire to foster the budding tradition in French Jesuit academic science ${ }^{59}$. He actively participated in the controversy over the calculus within the Académie during the early $1700 \mathrm{~s}^{60}$ and served a number of terms as président and viceprésident into the mid-1710s ${ }^{61}$. Gouye's early presentations to the assembly included contributions in the mode he had established for himself in his editing of the Jesuits' observations in Asia. He communicated his confrères' work to the Académie as a whole, selected « the least doubtful operations », provided calculations and conclusions which made the observations useful and relevant for the academicians' concerns, and secured academicians' responses ${ }^{62}$. After 1701, however, his communiqués

56. J. GalloIs, op. cit. supra n. 37, p. 137.

57. See F. C. Hsia, op. cit. supra n. 34.

58. MARS 1666-1699, t. VII, part. 2, p. 605-875.

59. For the Oratorian Nicolas Malebranche - Gouye's fellow honoraire - and his role in the Académie, see André RoBinet, "Le goupe malebranchiste introducteur du calcul infinitésimal en France ", Revue d'histoire des sciences, t. XIII, 1960, p. 287-308.

60. On the calculus controversy, see Michel BLAY, La Naissance de la mécanique analytique. La science du mouvement au tournant des xvif et xvır siècles, Paris, Presses universitaires de France, 1992, chap. II, and Paolo Mancosu, Philosophy of mathematics and mathematical practice in the seventeenth century, New York, Oxford University Press, 1996, p. $165-176$.

61. Gouye was président in 1711 , vice-président in $1707,1709,1710,1712,1713$, and 1715. See François Rozier, Nouvelle table des articles contenus dans les volumes de l'Académie royale des sciences, depuis 1666 jusqu'en 1770, Paris, Ruault, 1775, t. I, p. xux.

62. For Gouye's presentation of observations made by Fontenay and other French Jesuits in Asia, primarily astronomical, see HARS 1699, p. 51, 82-86; HARS 1701, p. 113; MARS 1701, p. 49-50; for Jacques Cassini and Giacomo Filippo Maraldi's commentary, see MARS 1701, p. 50-58. Gouye performed a similar function for other non-academicians, both Jesuit and lay, who sent their work to him, see HARS 1701, p. 109-110. 
decreased both in frequency and in content, and he abdicated the task of evaluating, refining, and working with his fellow Jesuits' reports to other academicians ${ }^{63}$.

At the beginning of 1716 , just after Gouye had completed what turned out to be his final term as vice-président, another règlement was announced for the Académie ${ }^{64}$. These articles governing the Académie's organization established a new class of membership, that of the associés libres. Like the honoraires, the associés libres were not attached to any particular field of scientific investigation; like the honoraires, the associés libres were permanently excluded from the hierarchical ladder of pensioned academicians; and finally, the associés libres were usually elected with a level of "governmental influence " far stronger than that exerted with respect to the appointment of individuals to regular places in the Académie's hierarchy ${ }^{65}$.

But there were three important differences between these two categories of Académie membership. First, the président and vice-président were annually chosen from among the honoraires alone ${ }^{66}$. Secondly, the associés libres had no vote in the assembly when it came to matters having to do with « election or affairs concerning the Académie ${ }^{67} »$. These conditions were consistent with those set forth in the Académie's charter règlement concerning the prerogatives of honoraires and associés. The final, and crucial difference between these two classes of membership - and one enacted by the 1716 articles as a modification of the standing regulations - was this : henceforth, members of religious orders could no longer be proposed for a place among the honoraires. Instead, they were to be eligible only for a place as an associé libre ${ }^{68}$.

The reasons behind this new regulation may well have much to do with broader and long-standing concerns over the dual identity of religious aca-

63. After 1701, Gouye's reports to the Académie conveyed material sent to him from the Americas or from the French provinces. Where Académie astronomers discussed work carried out by French Jesuits in Asia, they were concerned with observations performed before 1700 . See e. g. HARS 1702, p. 86; HARS 1703, p. 39; HARS 1704, p. 42; HARS 1706, p. 113-114; MARS 1706, p. 481-482 (La Hire); MARS 1707, p. 123 (La Hire); MARS 1707, p. 200-202 (La Hire); MARS 1707, p. 367-368 (Cassini); and MARS 1707, p. 381-382 (La Hire).

64. See D. J. Sturdy, op. cit. supra n. 46, p. 421-422.

65. See L. Aucoc, op. cit. supra n. 31, p. XCIII-XCV (for the 1716 règlement), and p. LXXXIX (for article 32 of the 1699 règlement concerning associés); on " governmental influence » in these appointments, see R. HAHN, op. cit. supra n. 31, p. 80-81; on the hierarchical " career ladder ", see James E. MCClELlan, " The Académie royale des sciences, 1699-1793. A statistical portrait ", Isis, t. LXXII, 1981, p. 546-549.

66. See L. Aucoc, op. cit. supra n. 31, p. LXXXrv, article 3 of the 1699 règlement; the same point was reiterated in the 1716 règlement (p. XCv).

67. See ibid., p. LxxxIx, article 33 of the 1699 règlement.

68. Ibid., p. xcIII. 
demicians ${ }^{69}$. Yet there is some evidence which suggests that the Jesuits, and Gouye in particular, were squarely implicated in the revision of the Académie's governing articles. Certainly Gouye had been the only religious academician who had served as président and vice-président since the establishment of formal ranks in 1699; neither the Carmelite, Sébastien Truchet, nor the Oratorian, Nicolas Malebranche, his fellow religious honoraires of 1699 , had done so ${ }^{70}$. The Paris antiquarian Nicolas Fréret told Gaubil some years later : «Vos P.P. de Paris ont cru que c'estoit contre eux que ce règlement avoit esté fait et peut estre le ton que le R.P. Gouye avoit pris lorqu'il avoit rempli ces Places [of président and viceprésident] dans l'Académie avoit-il fait désirer le Règlement. " Fréret suggested further that the Parisian Jesuits' interpretation of events had led Louis-Bertrand Castel, Gouye's successor as professor of mathematics at the Jesuits' collège in Paris, to later « declare open war with the Académie des sciences $\gg$ in the pages of the Jesuit Journal de Trévoux ${ }^{71}$.

At the least, we may surmise that by the time that Gaubil and Jacques entered the China mission in 1722, Gouye was in no position to mediate relations with the Académie. Yet Souciet boasted in his preface to the Observations (1729) that both Gaubil and Jacques, before departing for China, « had time to confer several times with M. Cassini and M. Maraldi at the Observatory, and left full of good will and desire to be useful to Europe for the Arts and Sciences », thus implying that the Jesuits and the academicians had come to some understanding over the Jesuits' scientific work in China ${ }^{72}$. Eager to establish a working relationship with the astronomers of the Académie, Gaubil relied on Parisian Jesuits to forward his materials. Just a few months after arriving in Canton, Gaubil sent various observations to Souciet in Paris with a covering note that « If Your Reverence sees something worthy of being shown to the messieurs of the Observatory, it would please me for you to do so $^{73}$ ", and over the next several years, Gaubil regularly reminded Souciet, « his channel to the messieurs of the Académie des sciences », to communicate his work to the academi-

69. Michael S. Mahoney has suggested to me with respect to the 1699 règlement and the restriction of religious to the position of honoraire that members of religious orders were perceived as more likely to bring controversial baggage with them into the Académie. See also Daniel Roche, Le Siècle des lumières en province, Paris, Mouton \& Cie/École des hautes études en sciences sociales, 1978, t. I, p. 205-206.

70. See F. RozIER, op. cit. supra n. 61, t. I, p. XIX-xX.

71. Fréret-Gaubil, 8 Aug. 1737, in Virgile PINOT, Documents inédits relatifs à la connaissance de la Chine en France de 1685 à 1740, Genève, Slatkine Reprints, 1971, p. 156. On Castel's conflicts with the Académie in the late 1720 s, see Donald S. ScHiER, Louis Bertrand Castel, anti-Newtonian scientist, Cedar Rapids, The Torch Press, 1941, p. 18-22, 45-46.

72. É. Souciet, op. cit. supra n. $16, \mathrm{t} .1, \mathrm{p} . \mathrm{x}$.

73. See R. Simon, op. cit. supra n. 10 , Gaubil-Souciet, 12 Nov. 1722, p. 34. Gaubil had arrived in Canton in late June 1722, see p. 33. 
cians $^{74}$. Gaubil dutifully directed material to the Académie astronomers every year, making sure that his writings were dispatched from Peking in time for the European ships' annual return voyage ${ }^{75}$.

In 1729, Gaubil assured the academician Jean-Jacques Dortous de Mairan : «Je continuerai à travailler, bien résolu de communiquer le tout à MM. de l'Académie, et j'espère qu'ils m'honoreront de leurs lumières et de leurs instructions ${ }^{76}$. » But this was an expression of hope for future cooperation, not of confidence in a well-established and long-term correspondence. Despite his Parisian contacts, Gaubil found that exchange with the Paris academicians was almost entirely a one-sided affair. The Académie astronomers offered bland encouragements and asked him for more material, but gave little in return. By the late 1720 s, Gaubil was bitterly complaining that Cassini and Maraldi had «said nothing detailed » to him in their letter, and he warned that the Académie astronomers would receive nothing more until they sent him "something other than compliments " 7 .

Parennin had launched a parallel campaign from Peking in 1723 to resume French Jesuit contact with the Académie, probably encouraged by Gaubil and Jacques' enthusiastic efforts ${ }^{78}$. Addressing himself to Bernard Le Bovier de Fontenelle, secretary of the Académie, Parennin presented the academicians with a beautiful set of volumes bound in yellow silk and written in Manchu. Though Parennin expected that the academicians would be surprised to receive such a gift, he explained that the text was in fact his translation of their own works in human anatomy and medicine, carried out at the K'ang-hsi emperor's request ${ }^{79}$. More items accompanied a second letter in which Parennin carefully described the Chinese materia medica he sent to the Académie, their use, and the plants and waters from which they were derived ${ }^{80}$. Fontenelle acknowledged Parennin's flattering gifts and letters in the Académie's Histoire for 1726, thanking Parennin for praising

74. Ibid., Gaubil-Louis Gaillard, S.J., 23 July 1725 , p. 68.

75. Ibid., Gaubil's letters to Souciet: 12 Dec. 1722 , p. $36 ; 18$ Aug. 1723, p. $61 ; 20$ Oct. 1723 , p. $62-63 ; 8$ Oct. 1724 , p. $65 ; 25$ Oct. 1725 , p. 84,$86 ; 31$ Oct. 1725 , p. $93-95 ; 5$ Nov. 1725 , p. $97-98 ; 5$ Nov. 1725 , p. $103-107 ; 9$ Nov. 1725 , p. $109-111 ; 26$ Nov. 1725 , p. 119 ; 6 Oct. 1726 , p. $121 ; 21$ Oct. 1726 , p. $126 ; 14$ Oct. 1727 , p. $193 ; 17$ Nov. 1728 , p. 209 ; 19 Nov. 1728 , p. $213 ; 18$ Oct. 1729 , p. $243 ; 24$ Oct. 1729 , p. $248 ; 16$ Sept. 1730 , p. $257-258$. Gaubil also attempted contact with the academician Pierre Mahieu, apparently to no avail; see ibid., Gaubil-Souciet, 20 Oct. 1723 , p. $62 ; 25$ Oct. 1725, p. 86; 21 Oct. 1726, p. 126.

76. Ibid., Gaubil-Mairan, 10 Oct. 1729, p. 225.

77. Ibid., Gaubil-Souciet, 10 Oct. 1729, p. 232-233; ibid., Gaubil-Julien Placide Hervieu, 24 Nov. 1728 , p. 216.

78. Ibid., Gaubil-Souciet, 20 Oct. 1723, p. 63.

79. See $L E C$, t. III, Parennin-Fontenelle, 1 May 1723 , p. 330.

80. See $L E C$, t. III, Parennin-Fontenelle, 15 Oct. 1723 , p. 340-346. This letter was published without a date in the $L E C$; see Yvonne GROVER, « Correspondance scientifique du père Dominique Parennin ", in Actes du Ir colloque international de Sinologie. Les rapports entre la Chine et l'Europe au temps des Lumières (Chantilly), Paris, Les Belles Lettres, 1980, p. 84-85. 
the Académie's labors to the emperor and remarking that the present was both « considerable " and "very conformable " to the Académie's taste; René-Antoine Ferchault de Réaumur read a paper on the Chinese medicines to the Académie, which was chosen for publication in the Mémoires $^{81}$.

But three years after the procurator for the French Jesuit mission in China, Pierre de Goville, had personally handed Parennin's missives to Fontenelle in Paris, Jacques wrote from Peking to Souciet with great anxiety. Why had the academician not responded to the French Jesuits at Peking? Were not the items sufficiently «curious »? Both Goville and Jacques suspected that Fontenelle's silence was a sign of irritation with their confrère Jean-Baptiste Du Halde. Editor of the Lettres édifiantes et curieuses since Le Gobien's death in 1708, Du Halde had " printed in his collections a part of what Parennin had sent ", taking advantage of Goville's courtesy in giving Du Halde a copy of Parennin's materials ${ }^{82}$. Jacques spelled out his views in no uncertain terms : Du Halde's journal could not be allowed to interfere with the French Jesuits' obligations to the Académie. The French Jesuits at Peking contributed to the Lettres édifiantes «with pleasure and even with ardor», Jacques wrote, but he went to argue that

"we must be linked with the Messieurs of the Académie, and these Messieurs must be content with us. Such is the intention of the King, our illustrious founder, such are the intentions of the superiors of the Company who have often sent their orders concerning this to China. Such are our true interests ${ }^{83}$.

Jacques made his criticisms of Du Halde without having seen the Académie's Histoire et mémoires for 1726 . Had he done so, he would have found further justification for his suspicions ${ }^{84}$. Fontenelle prefaced his remarks in the Histoire on Parennin's materials by commenting that there was no better way for the Académie to express its gratitude than to « expose to the public " the value of Parennin's gift, though it could only do so in a " rather brief manner ": "Nous ne parlerons que de deux de ces drogues,

81. HARS 1726, p. 17. Fontenelle's account is found on p. 17-20; Réaumur's memoir, dated 21 Aug. 1726, is in MARS 1726, p. 302-305.

82. Jacques-Souciet, 1 Nov. 1727, REO, t. III, 1887, p. 222.

83. Ibid. Jean-Baptiste Du Halde's confrères in Peking grew increasingly wary of his incessant requests for materials for the Lettres édifiantes, suspecting him of blocking their efforts to establish correspondence with lay savants, and viewing Du Halde himself as ineffectual in obtaining either audience for their work or support for the mission. See R. Simon, op. cit. supra n. 10, Gaubil-Souciet, 13 Nov. 1725, p. 117; Gaubil-Souciet, 21 Oct. 1726, p. 120; Gaubil-Souciet, 19 Nov. 1728, p. 211 and 213.

84. A 1731 wishlist of European books, signed by Parennin, specified that the French Jesuit residence in Peking did not possess the Académie's annual volumes published after 1725; see R. Simon, op. cit. supra n. 10, p. 298. 
\& le public n'y perdra rien, puisque tout ce qu'a écrit ce sçavant Missionnaire sera imprimé dans un ouvrage qui appartient à sa compagnie, dont nous respectons le droit légitime ${ }^{85}$. " Fontenelle went on to expose Parennin's naive acceptance of Chinese beliefs concerning one of the medicines, called the Hia-tsao-tomtchom, meaning "a plant in the summer and a worm in the winter ». Parennin had sent the Académie some three hundred examples of this rare plant which marvelously resembled nothing less than a long yellowish worm, complete with head, eyes, and feet, commenting that he had been able to find out neither «the form of its leaves, nor the color of the flowers it bears, nor the height of its stem ${ }^{86}$. Fontenelle loftily explained that "the same thing which makes it a marvel for the Chinese, and would make it one as well for the French common folk " as it had for Parennin himself - was what « destroyed it for the Academy : we very quickly perceived that it was really the cast-off skin of some caterpillar, and M. de Réaumur fully assured himself of this through a more particular examination " ${ }^{87}$. The entire episode did little to raise the repute of French Jesuit contributions towards «the perfection of the arts and sciences », and widened the gap between academicians and Jesuits even further ${ }^{88}$.

Even Souciet's efforts to maximize the importance of his confrères' work for a lay savant audience must be counted as a failure. The publication of the Observations in 1729 made only too clear how little contact the French Jesuits had with the Academie. Whereas the title pages to Gouye's volumes of 1688 and 1692 proclaimed that the French Jesuits' observations had been sent to the Académie royale des sciences, Souciet could make no similar claim in the title of his edition. And although Souciet reported that he had passed the Jesuits' scientific work on to «MM. de l'Observatoire » who had « approved them », he was unable to secure very much in the way of academicians' commentary for publication ${ }^{89}$. Only a few short comments by the Académie astronomers on Gaubil and Jacques' work nearly all of which had already been published in the Académie's Mémoires for 1726 - were included in the body of the text, in contrast to

85. HARS 1726, p. $17,19$.

86. HARS 1726, p. 19; MARS 1726, p. 303; Parennin-Fontenelle, 15 Oct. 1723, in $L E C$, t. III, p. 340.

87. HARS 1726, p. 19-20; see MARS 1726, Réaumur's memoir, p. 302-305. For a contemporary evaluation of this Chinese medicine, see Y. Grover, art. cit. supra n. 80, p. 88.

88. See MARS 1727, René-Antoine Ferchault de Réaumur, « Idée générale des différentes manières dont on peut faire la Porcelaine; \& quelles sont les véritables matières de celle de la Chine ", 26 April 1727, which included a disdainful critique of Dentrecolles' earlier contribution on porcelain to the Lettres édifiantes.

89. E. Souciet, op. cit. supra n. 16 , t. I, p. XVII. 
the extensive « réflexions » by academicians which Gouye had been able to publish with his confrères' observations ${ }^{90}$.

Souciet's editorial work in 1729 did not live up to the standard Gouye had set in the earlier Observations. Self-conscious that his own expertise lay in the realm of textual criticism, Souciet confessed in the preface to some insecurity about the way he had organized the materials and especially the astronomical observations, writing that if « another order pleases connoisseurs more, I will gladly follow it in the collections that I may subsequently publish ${ }^{91} \gg$. Though the volume received a measuredly favorable review in the Journal des savants, Gaubil found the text execrable ${ }^{92}$. A few days after four copies of the Observations arrived in Peking in the summer of 1731, Gaubil wrote Souciet with as much courtesy as he could muster, suggesting along with his fellow Jesuits at Peking that « Your Reverence, not having the leisure to produce the edition yourself, has given this commission to someone who has given it very little care. " Gaubil went on to declare that there was an "infinity " of errors in the text, which he patiently listed, page by page and line by line ${ }^{93}$. Recordings of solar eclipses had been repeated a few pages later as observations of lunar eclipses; determinations of longitude had been wrongly concluded; rivers incorrectly positioned; romanizations of Chinese place-names given inconsistently. Observations of magnetic declination were said to have been used to establish the geographical position of the Great Wall, while an alphabetical list of longitudes and latitudes in Asia - compiled by Souciet - included longitudes based on different prime meridians, despite Souciet's claim to have reduced all the positions given to the meridian of Paris $^{94}$. It was « unfortunate », wrote Gaubil, that the book had been dedicated to the king ${ }^{95}$. Most importantly, the Jesuits' observations had not been systematically put in a context of contemporary scientific work. Gaubil politely but firmly suggested that Souciet « share this labor either with some other knowledgeable Jesuit, or with some astronomer at Paris ", claiming that Gouye's volumes had succeeded precisely because of Cassini's and La Hire's assistance ${ }^{96}$.

90. Ibid., p. 49, 82-83, 87-88 for Cassini/Maraldi-Gaubil, 9 Dec. 1726; p. 106 for Cassini/ Maraldi-Gaubil, Nov. 1728. See MARS 1726, p. 236-242.

91. E. SoucIET, op. cit. supra n. 16, t. I, p. XIX. Souciet reflected at length on his editorial decisions, see p. xviII-Xxv. For Souciet's own works, see Carlos Sommervogel, Bibliothèque de la Compagnie de Jésus, 12 vol., Brussels/Paris, Oscar Schepens/Alphonse Picard, 18901910, sub nom.

92. JS, Nov. 1729 , p. $657-660$.

93. See R. Simon, op. cit. supra n. 10, Gaubil-Souciet, 16 Aug. 1731, p. 274.

94. Ibid., Gaubil-Souciet, 1731, « Fautes à corriger », p. 282-288, and É. SoucIET, op. cit. supra n. 16, t. I, p. XXIII-XXIV.

95. See R. Simon, op. cit. supra n. 10, Gaubil-Souciet, 16 Aug. 1731, p. 274.

96. Ibid., p. 275. 
Souciet's liabilities as an editor and as a mediator for his confrères' scientific activities not only endangered Gaubil's fragile relations with other Jesuits who had agreed to send their work to France, especially those associated with the Portuguese mission in China and charged with the direction of the imperial Astronomical Bureau ${ }^{97}$. More broadly, Gaubil feared that problems which marred this volume of Jesuit Observations would prejudice its European audience against future such collections and arouse little support for the French Jesuits, thus invalidating the principal justification for French scientific labor which Gaubil proposed to largely unsympathetic members of his own order.

\section{A FRENCH JESUIT OBSERVATORY IN PEKING}

Gaubil looked back to the early days of the French Jesuit mission in China as a sort of golden age, writing that « when the late king sent Fathers Gerbillon, Fontenay, Bouvet, Visdelou, Lecomte here, the times were favorable. They took a little more interest in China than they do today ». His hope was to carry on « according to the plan given to these early missionaries », but this seemed increasingly impossible : "I've written about it to the reverend fathers Linière, Orry, Souciet, but things are always at the same dead end ${ }^{98}$. " It was not simply the lack of stable and productive relations with lay savants that frustrated Gaubil's attempt to revive French Jesuit scientific activity in China, but many of his fellow Jesuits as well. He fought an uphill battle against his superiors in France and his confrères in China for items necessary to his research : instruments, journals, ephemerides, contemporary reports of astronomical observations. Unlike the members of the initial French Jesuit voyages to China, who had come richly supplied with the materials necessary to carry out their scientific duties, Gaubil and Jacques had left France with little in the way of such provisions ${ }^{99}$. As even Souciet admitted, the observations which the two Jesuits nonetheless succeeded in making en route to China were largely the product of their ingenuity ${ }^{100}$.

97. For Gaubil's relations with Ignatius Kögler, see R. Simon, op. cit. supra n. 10 : GaubilSouciet, 28 June 1726 , p. $119 ; 6$ Oct. 1726 , p. $121 ; 26$ Nov. 1728 , p. $219 ; 24$ Oct. 1729, p. 246; for the reaction of Kögler and other Jesuits in Peking to the Observations (1729), see ibid., Gaubil-Souciet, 1731, p. 280, 281, and 6 Nov. 1731, p. 297.

98. Ibid., Gaubil-Fréret, 5 Nov. 1734, p. 403-404. Claude Bertrand Tachereau de Linières was confessor to Louis XV.

99. See G. TACHARD's lengthy description of the scientific preparations for the 1685 mission in the opening pages of his Voyage de Siam, op. cit. supra n. 27.

100. É. SoucIET, op. cit. supra n. 16, t. I, p. XI. Gaubil remarked more than once on this frustration in his letters to Souciet, noting, for instance, that an occultation of Saturn with the 
In late 1722, just before leaving Canton for the imperial capital, Gaubil asked Souciet for « a good telescope with a micrometer », assuming that he would find more instruments in Peking ${ }^{101}$. Gaubil arrived in the capital, however, to find that the scientific instruments belonging to the French Jesuit mission had, since Fontenay's time, nearly all been « spoiled, or lost, or put in unknown places ", and he and Jacques had much difficulty restoring them to a point where they could be of use ${ }^{102}$. In Gaubil's opinion, it was the lack of a proper site for observation that had led to such a state of affairs ${ }^{103}$. This was but one of the reasons that he put forth to argue the necessity of building " a little observatory " at the French Jesuit house in Peking. Gaubil vividly described the impossibility of conducting regular astronomical work, lamenting that " every time one wants to observe, one must transport the instruments, which ruins them ", and the observations suffered accordingly ${ }^{104}$. He made some modest calculations of the expense for his little project, and waited. Even though Gaubil made clear that he had nothing elaborate in mind - merely « a place where one can put an instrument on a meridian [and] set up three or four telescopes and a pendulum, from where one can see on all sides », not « an observatory like the one at Paris »- his request was poorly received ${ }^{105}$. One of his Jesuit correspondents suggested to him that he climb on the roof of the church to make observations. His confrères in France remarked further the French Jesuit mission in Peking had done without an observatory for all these years; why was one so urgently needed now ${ }^{106}$ ?

The ephemerides which Gaubil and Jacques had brought to China in 1722 only extended to the year 1725 , and Gaubil repeatedly requested a new set, to no avail ${ }^{107}$. With no current ephemerides and no micrometer, wrote Gaubil, the French Jesuits at Peking were " ridiculous " in the eyes of their Jesuit brethren ${ }^{108}$. Request for European journals and recently published texts met with similar resistance. The Peking house lacked certain numbers of the Académie's annual memoirs, the Jesuit Journal de Trévoux, the Acta eruditorum, but Gaubil's local superior, Dominique Parennin, told him that it had been decided to send no more journals to China

\footnotetext{
moon had to go unrecorded, "faute d'instruments", see in R. Simon, op. cit. supra n. 10, Gaubil-Souciet, 23 Feb. 1722, p. 10; see also 12 Nov. 1722, p. 33-34; 12 Dec. 1722, p. 35-36. 101. See R. Simon, op. cit. supra n. 10, Gaubil-Souciet, 12 Dec. 1722, p. 36.

102. Ibid., Gaubil-Souciet, 23 Oct. 1731 , p. $292 ; 30$ oct. 1723 , p. 63.

103. Ibid., Gaubil-Souciet, 23 Oct. 1731, p. 292.

104. Ibid., Gaubil-Souciet, 24 Oct. 1729, p. 247.

105. Ibid., Gaubil-Souciet, 23 Oct. 1731, p. 292 ; Gaubil-?, ca. 1733, p. 356.

106. Ibid., Gaubil-Souciet?, ca. 1733, p. 356-357.

107. Ibid., Gaubil-Souciet, 12 Nov. 1722 , p. $34 ; 25$ Oct. 1725 , p. $86 ; 12$ Nov. 1725 ,

p. $113 ; 10$ Nov. 1726 , p. $133 ; 8$ Nov. 1728 , p. $208 ; 19$ Nov. 1728 , p. 211.

108. Ibid., Gaubil-Souciet, 10 Nov. 1726, p. 133.
} 
because of the cost ${ }^{109}$. Gaubil made lists of mathematical and astronomical books authored by Jesuits, texts by John Flamsteed and Edmund Halley, new maps, the Philosophical Transactions and the Miscellanea Berolinensia $^{110}$. Though Parennin approved his requests, Gaubil was forced to ask the Portuguese mission for many of the items, adding insult to injury ${ }^{111}$. After the fiasco of the Observations and in the midst of his disagreements with his confrères over the value of astronomical work, Gaubil wrote sourly :

"Au collège des Portugais, on observe beaucoup, on y a reçu de grands secours en argent, et autres choses, et aujourd'hui, on y a de grandes lunettes et des machines pour s'en servir, de grands quarts de cercle, de bonnes pendules, qui sont venues d'Angleterre, et d'excellents livres venus d'Angleterre. Depuis qu'ils voient que dans cette maison on ne fait presque point d'observation, ils ont renouvelé et redoublé leurs soins. J'ai demandé leurs observations pour V[ôtre] R[everence], je crois que vous n'aurés d'eux que bien peu de chose, le meilleur ira je pense à Pétersbourg et à Lisboa ${ }^{112}$."

Gaubil faced problems closer to home as well. He confided to Souciet that he had been pressured by fellow Jesuits in Peking to divert monies Souciet had sent to him for his astronomical work to other purposes ${ }^{113}$. Gaubil complained that the French mission's superior general, Julien Placide Hervieu, had allowed Parennin to do as he willed as superior of the French residence in Peking, and "celui-ci m'a si fort contrarié et si peu secouru que j'ai été sur le point de quitter Pékin, d'aller à Macao et de là m'aller cacher dans quelque coin de nos missions pour aider les chrétiens ${ }^{114} \%$. If the matter of the proposed observatory were left up to Parennin, wrote Gaubil, the few instruments left would be sold off ${ }^{115}$. Jacques, the Jesuit who had journeyed to China together with Gaubil in 1721 , was a willing if inexperienced companion to Gaubil's astronomical work. His poor health, however, meant that what assistance he could provide was severely limited ${ }^{116}$. Jacques' illness and premature death in 1728

109. Ibid., Gaubil-Souciet, 14 Oct. 1729, p. 238.

110. See, ibid., p. 298-299, Gaubil's list of books sent to the Paris procurator for the mission, P. Charles de Frémont, (1731).

111. Ibid., Gaubil-Souciet, 23 Oct. 1731, p. 290; Gaubil-Souciet, 6 Nov. 1731, p. 296; Gaubil's letters to Souciet in 1732, p. 332-340, and on the 19 Sept. 1733, p. 354-355; ibid., Gaubil-Delisle, 13 July 1734, p. 375-376; ibid., Gaubil-Souciet, 8 Nov. 1735, p. 427-428.

112. Ibid., Gaubil-Souciet, 8 Oct. 1733 , p. 358-359.

113. Ibid., Gaubil-Souciet?, 8 Oct. 1733, p. 359, and Gaubil-Souciet, 8 Nov. 1735, p. 427.

114. Ibid., Gaubil-Souciet, 8 Nov. 1735, p. 426.

115. Ibid., Gaubil-Souciet?, 8 Oct. 1733 , p. 358.

116. For comments on Jacques' inability to help with astronomical work, see ibid., GaubilSouciet, 5 Nov. 1725 , p. 106 ; 28 June 1726, p. 120 ; 6 Oct. 1725 , p. 121 ; 10 Nov. 1726, p. $133 ; 21$ Nov. 1726 , p. $138 ; 23$ Feb. 1722, p. 10 . See also É. Souciet, op. cit. supra n. 16, t. I, p. $x$. 
nevertheless adversely affected Gaubil's log of observations, and Gaubil looked forward to the arrival of two younger confrères on the mission in $1729^{117}$. He quickly set the new missionaries to learning different observational tasks : Valentin Challier to the determination of local time by the method of « equal altitudes », Alexandre de Lacharme to practice independently making and recording observations of eclipses ${ }^{118}$. The Jesuit brother Étienne Rousset, a physician who had entered China a few years before Gaubil himself, marked time according to the pendulum ${ }^{119}$. A few years later, Gaubil reported that Lacharme was progressing well in his observational work, and requested a few copies of the introduction to Eustachio Manfredi's ephemerides, which he possibly intended as reference manuals for his younger colleagues ${ }^{120}$. This group was the closest Gaubil ever came to forming a group within the French Jesuit mission dedicated to astronomical observation. The difficulties Gaubil had faced as an astronomer in Peking for a decade turned out to be too much for the younger Lacharme, discouraged by the lack of instruments, his superiors' indifference, and the Académie astronomers' silence ${ }^{121}$. Gaubil confessed in 1733: «Voici le peu d'observations que je puis vous envoyer. Le P. Lacharme s'est dégoûté et a été dégoûté ${ }^{122}$."

There was, then, considerable difficulty in mobilizing the French Jesuit community itself in favor of resuming astronomical work in China. Jesuit critics at Paris complained that they could not see the use of the telescopes, micrometers, and ephemerides which Gaubil finally received in $1728^{123}$; Gaubil's confrères in China gave little priority to his efforts to reinstate a program of continuous astronomical observations ${ }^{124}$. The importance of such activity in the French Jesuit mission was no longer self-evident, even to the Jesuits themselves.

117. See R. Simon, op. cit. supra n. 10, Gaubil-Souciet, 17 Nov. 1728, p. 209.

118. Ibid., Gaubil-Souciet, 11 Aug. 1730, p. 251-253; Gaubil-Souciet, 16 Sept. 1730, p. 259; Gaubil-Delisle, 20 May 1732, p. 309.

119. Étienne Rousset had previously assisted Gaubil and Jacques; see ibid., GaubilSouciet?, n. d., p. 357.

120. Ibid., Gaubil-Souciet, 23 Oct. 1731, p. 293. For Manfredi, see ibid., Gaubil-Souciet, 23 Oct. 1731 , p. 291,6 Nov. 1731 , p. 296 ; and 6 Nov. 1732, p. 347. Eustachio MANFrEDI, Ephemerides montuum coelestium [...] Cassinianis tabulis ad meridianum Bononiae supputatae, Bologna, 1715.

121. See R. Simon, op. cit. supra n. 10, Gaubil, 1733?, p. 357, and Gaubil-Souciet, 20 Oct. 1736, p. 454.

122. Ibid., Gaubil-Souciet?, 8 Oct. 1733, p. 358.

123. Ibid., Gaubil-Hervieu, 24 Nov. 1728, p. 217 , and Gaubil-Souciet, 26 Nov. 1728, p. 220 .

124. See esp. ibid., Gaubil-Hervieu, ibid., 24 Nov. 1728, ibid., p. 215. 
By the 1720s, astronomical observation - once the centerpiece of an Académie-endorsed program for the fledgling French Jesuit scientific mission - was but one of several competing forms of intellectual capital which Jesuits in China hoped to trade for the subsistence of their missions. Half a league away from the French Jesuit residence in Peking, Kögler and the other Jesuit astronomers of the Portuguese-supported mission occupied the center of an extensive and productive network of lay and Jesuit colleagues. They received materials from Rome, Paris, the German territories, even England; they knew Jesuit astronomers «attentive » to sending contemporary European materials to Peking, who would « show off in Europe » what the Peking astronomers sent in return ${ }^{125}$. In the face of such success, one can understand both Gaubil's desire to exploit his own talents in observational astronomy for the good of the French mission, as well as his fellow Jesuits' willingness to abandon the field to the Portuguese mis$\operatorname{sion}^{126}$.

The French Jesuit scientific mission had come a long way from Lecomte's dreams for French Jesuit observatories in China, at "Isfahan in Persia, at Agra in the Mogul [empire], on the Isle of Borneo below the Equator, in Tartary » and elsewhere ${ }^{127}$. Such ambitions, articulated in a flush of initial success in importing a French academic brand of scientific work to the China mission, soon dissipated. Anticipating claims made much later from outside the metropole that provincial academicians in France and Parisian academicians together comprised « un seul Corps», French Jesuits argued in the early years of the mission that French Jesuits in China and academicians in Paris, through their coordinated efforts, formed « un même Corps d'Académiciens, les uns en France \& les autres à la Chine $»$ working together to perfect the sciences ${ }^{128}$. But over time, the Académie became unwilling to grant the Jesuits this level of parity. Fontenelle was quick to point out that the academician Dortous de Mairan opened a correspondence with Parennin as a private individual, after the Académie

125. Ibid., Gaubil-Souciet, 24 Oct. 1729 , p. 246, and 23 Oct. 1731 , p. 289 ; see also ibid. : Gaubil-Delisle, 20 May 1732, p. 309; Gaubil-Souciet, 25 Sept. 1732, p. 339-340; GaubilSouciet, 8 Nov. 1735 , p. 426; Gaubil-Souciet, 3 Nov. 1738 , p. 307 . On the location of the French and Portuguese Jesuit houses in Peking, see ibid., Gaubil-Delisle, 20 May 1732, p. 307.

126. See REO, t. III, 1887, Jacques-Souciet, 1 Nov. 1727 , $R E O$, t. 3,1887 , p. 222 . Though Parennin had been discouraged by Fontenelle's initial rebuff, he later succeeded in engaging Dortous de Mairan in a wide-ranging and extended correspondence, in which Parennin spoke broadly as a generalist on matters Chinese, not as a specialist in Chinese materia medica; see Parennin's letters to Mairan in the $L E C$ and Jean-Jacques Dortous DE MAIran, Lettres de M. De Mairan au R.P. Parennin, missionnaire de la Compagnie de Jésus à Pékin, contenant diverses questions sur la Chine, Paris, De Saint \& Saillant, 1759.

127. L. D. LeCOMTE, op. cit. supra n. 6, p. 507. 
« en corps eut fait son devoir à l'égard du P. Parennin » in acknowledging the Jesuit's letters and gifts ${ }^{129}$. When Gaubil told Fréret that he found it hard to believe that a corps comprised of men as « wise » as those of the Académie had taken Gouye's attitude as a reason to exclude religious from the class of honoraire - adding that it was inexcusable to hold a corps accountable for what was true of only one of its members - Fréret noted to himself : «Les Corps se craignent mutuellement ${ }^{130}$. 》 The French Jesuit «Académie » in China had set a high bar of recognition for its work. Claiming, in essence, status as arguably the most far-flung "provincial " academy founded in the wake of the Paris Académie des sciences' establishment, French Jesuits sought recognition as a corporate body of investigators of nature. The difficulties of sustaining such a venture proved beyond the means of French Jesuit resources. Without mediators to manage relations with academicians, editors to present Jesuit materials to a savant public, the current books, journals, and instruments needed to retain a viable presence within European scientific communities, and, most broadly, a shared sense of the continued relevance of scientific work for the mission, the French Jesuit « Académie de la Chine » dissolved, never to be reborn.

Florence C. Hsia (January 1999).

128. HARS 1712, p. 332 (Société royale des sciences de Montpellier); G. TACHARD, op. cit. supra n. 27, p. 8. See D. RocHE, op. cit. supra n. 69, t. I, chap. I.

129. HARS 1732, p. 21.

130. See R. Simon, op. cit. supra n. 10, Gaubil-Fréret, 2 Nov. 1738, p. 499, and p. 504, n. A. 